\title{
PPARס mediates IL15 metabolic actions in myotubes: Effects of hyperthermia
}

\author{
GEMMA FUSTER $^{1,2}$, SÍLVIA BUSQUETS ${ }^{1}$, MAITE FIGUERAS $^{1}$, ELISABET AMETLLER ${ }^{1}$, \\ CIBELY CRISTINE FONTES DE OLIVEIRA ${ }^{1}$, MIREIA OLIVÁN ${ }^{1}$, PAUL A. GRIMALDI ${ }^{3}$, \\ JOSEP M. ARGILÉS ${ }^{1}$ and FRANCISCO J. LÓPEZ-SORIANO ${ }^{1}$
}

\begin{abstract}
${ }^{1}$ Cancer Research Group, Departament de Bioquímica i Biologia Molecular, Facultat de Biologia, Universitat de Barcelona,
Diagonal 645; Institut de Biomedicina de la Universitat de Barcelona (IBUB), 08028 Barcelona, Spain;

${ }^{2}$ Centro de Investigación en Red de Enfermedades Respiratorias (CibeRes); ${ }^{3}$ INSERM U636, Université de

Nice-Sophia Antipolis, Centre de Biochimie, Parc Valrose, UFR Sciences, F-06108 Nice, France
\end{abstract}

Received January 13, 2009; Accepted March 16, 2009

DOI: 10.3892/ijmm_00000207

\begin{abstract}
C} 2 \mathrm{C} 12$ cells exposed to hyperthermia $\left(41^{\circ} \mathrm{C}\right)$ experienced an increase in both protein synthesis and degradation. The addition of IL15 under hyperthermic conditions resulted in an important increase in protein synthesis with no changes in protein degradation, except when cells overexpressed PPAR $\delta$. The PPAR $\delta$ agonist GW501516 exerted similar effects on protein synthesis to IL15. Expression of a mutant dominant negative form of PPAR $\delta$ prevented the effect of the cytokine on protein synthesis, suggesting that this transcription factor is involved in the anabolic action of IL15. The present study also suggests that the effects of IL15 on lipid oxidation could be mediated by PPAR $\delta$.
\end{abstract}

\section{Introduction}

Muscle wasting is a common feature in many pathological states including infection and cancer (1). While the main events related to muscle wasting are known [activation of myofibrillar protein degradation, induction of apoptosis, activation of uncoupling proteins (UCPs)] $(2,3)$, little information on the intracellular signaling pathways is available. These may play a key role, from a therapeutic point of view, especially if different mediators are involved. Some reports have postulated a role for NF- $\mathrm{\kappa B}$ (nuclear factor- $\mathrm{\kappa}$ ) in muscle wasting associated with cytokines (4) and tumour-derived factors (5). Other transcription factors, such as AP-1 (activator protein-1) and C/EBP (CCAATenhancer binding protein), have also been involved in sepsis-

Correspondence to: Dr Francisco J. López-Soriano, Cancer Research Group, Departament de Bioquímica i Biologia Molecular, Facultat de Biologia, Universitat de Barcelona, Diagonal 645, 08028 Barcelona, Spain

E-mail: flopez@ub.edu

Key words: IL15, PPARd, protein hypercatabolism induced muscle cachexia (6). Data from our laboratory indicate that the transcription factor AP-1 could also be involved during cancer cachexia $(7,8)$. Not much attention has been focused on the role of PPARs in skeletal muscle. These transcription factors are associated with changes in lipid metabolism as well as UCP expression (9) and apoptosis (10).

PPARs are transcription factors belonging to the superfamily of nuclear receptors. Three isoforms $(\alpha, \gamma$ and $\delta$ ) have been described. The PPARs are the major regulators of lipid and glucose metabolism, allowing adaptation to the prevailing nutritional environment (11). PPARS has a broad expression pattern in the adult and is expressed very early during embryogenesis (12). During the past few years it has been demonstrated that treatment with PPAR $\delta$ agonists normalizes blood lipids and also reduces insulin resistance and adiposity both in rodents and primates (12). Work utilizing cellular and animal models revealed that this nuclear receptor plays a central role in the control of fatty acid burning in adipose tissue and skeletal muscle (12). Furthermore, PPAR $\delta$ appeared to be important for the adaptive response of skeletal muscle to environmental changes, such as physical exercise (12).

We have previously demonstrated that interleukin-15 (IL15) can act as an anabolic factor for skeletal muscle influencing protein metabolism both in vivo (13) and in vitro (14). In connection to lipid metabolism, in the course of in vivo studies regarding the effects of IL15 on skeletal muscle, a 33\% decrease in WAT mass was observed in rats, with no changes in food intake (15). In another study using obese rodent models, a correlation was found between the sensitivity to the fatinhibiting effects of IL15 and the fat expression of mRNA for key signaling subunits of the IL15 receptor in WAT (16), suggesting that IL15 may have a direct effect on this tissue. Additionally, a direct inhibition by this cytokine of adipogenesis has been reported in 3T3-L1 cells, confirming the direct action of IL15 in adipose tissue (17). Recent data from our research group point out a novel mechanism of IL15 action, suggesting that this cytokine increases in vivo fatty acid oxidation by upregulation of PPAR $\delta$ and other lipid 
oxidation-related genes in both muscle and liver (18). The aim of the present investigation was to elucidate the possible role of PPARS in the actions of IL15 on cultured muscle cells exposed to hyperthermia.

\section{Materials and methods}

Cell culture. C2C12 mouse skeletal muscle cells were obtained from the American Type Culture Collection. Construction of the retroviral expression vectors for PPAR $\delta$ and PPAR $\delta$ dominant negative mutant and establishment of $\mathrm{C} 2 \mathrm{C} 12$ populations overexpressing either PPARS (referred as $\mathrm{C} 2 \mathrm{C} 12-$

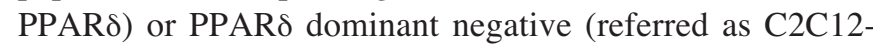
PPARסDN), have been previously described $(19,20)$. Cells were passaged in high-glucose Dulbecco's modified Eagle's medium (DMEM) supplemented with $10 \%$ fetal bovine serum (FBS), $100 \mathrm{U} / \mathrm{ml}$ penicillin, $100 \mu \mathrm{g} / \mathrm{ml}$ streptomycin, $25 \mathrm{ng} / \mathrm{ml}$ fungizone, $110 \mu \mathrm{g} / \mathrm{ml}$ sodium pyruvate, and $2 \mathrm{mM}$ L-glutamine, and in the case of genetically modified cells also with $0.4 \mathrm{mg} /$ $\mathrm{ml}$ of geneticin, in a humidified atmosphere of $5 \% \mathrm{CO}_{2}$ and $95 \%$ air at $37^{\circ} \mathrm{C}$. For experimental analyses, cells were seeded at $3.7 \times 10^{4}$ cells $/ \mathrm{cm}^{2}$ in $10 \%$ FBS/DMEM until they reached 90-100\% confluence $24 \mathrm{~h}$ later. At this time, the medium was replaced by DMEM containing $10 \%$ horse serum for induction of differentiation for genetically modified cells. Abundant myotube formation, monitored microscopically, occurred after 4 days in $10 \%$ horse serum (HS)/DMEM. Such fused myotube cultures were utilized for experimental analyses 5 days after transferring cells to $10 \% \mathrm{HS} / \mathrm{DMEM}$.

Punctual hyperthermia and measurement of protein degradation and protein synthesis. Parental C2C12, C2C12-

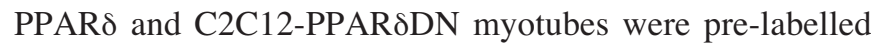
with L- $\left[2,6-{ }^{3} \mathrm{H}\right]$ phenylalanine as described (21) for a $24-\mathrm{h}$ period, after which they were washed extensively in PBS, and incubated in fresh DMEM for a 2 -h period at $37^{\circ} \mathrm{C}$, until no more radioactivity appeared in the medium. Protein degradation was measured by the release of $\left[2,6-{ }^{3} \mathrm{H}\right]$ phenylalanine into the medium after 6 -h incubation at $37^{\circ} \mathrm{C}$ or $41^{\circ} \mathrm{C}$ in the presence of $2 \mathrm{mM}$ cold phenylalanine to prevent reincorporation of the radio-label. The punctual hyperthermia method to induce protein degradation has been previously described by Smith and collaborators (22). Cultures were incubated with or without murine IL15 added at $10 \mathrm{ng} / \mathrm{ml}$ in PBS (PeProtech, London, UK) and the PPARd agonist GW501516 at $0.1 \mu \mathrm{M}$ (Alexis Biochemicals, Lausen, Switzerland) in DMSO:PBS (1:10000).

To determine the rate of protein synthesis, parental $\mathrm{C} 2 \mathrm{C} 12$, C2C12-PPAR $\delta$ and C2C12-PPAR $\delta$ DN myotubes were incubated in fresh DMEM for a 2 -h period at $37^{\circ} \mathrm{C}$, after which they were incubated for a 6 -h period at either $37^{\circ} \mathrm{C}$ or $41^{\circ} \mathrm{C}$ in DMEM-supplemented with $1 \%$ glutamine, $1 \%$ penicillinstreptomycin-fungizone and $10 \% \mathrm{HS}$. One hour before the end of the incubation, the culture medium was replaced with experimental medium containing $\left[2,6-{ }^{3} \mathrm{H}\right]$ phenylalanine. After the incubation, the cells were rinsed twice in PBS. The protein synthesis rate was measured by the presence of $[2,6-$ $\left.{ }^{3} \mathrm{H}\right]$ phenylalanine in cell protein extracts and the protein content was determined by the BCA method (Pierce, USA).
Fatty acid oxidation and uptake. In order to measure palmitate oxidation, parental $\mathrm{C} 2 \mathrm{C} 12$ and genetically modified myotubes were incubated for $3 \mathrm{~h}$ in a KHB medium containing $\left[1-{ }^{14} \mathrm{C}\right]-$ palmitate with or without $10 \mathrm{ng} / \mathrm{ml} \mathrm{IL15}$. The cells were incubated in a $25 \mathrm{~cm}^{2}$ flask with a special stopper in order to trap the ${ }^{14} \mathrm{CO}_{2}$ generated by oxidation of the labelled substrate. At the end of the 3-h incubation period, $200 \mu 1$ of $0.5 \mathrm{M}$ $\mathrm{H}_{2} \mathrm{SO}_{4}$ were added to the medium and $200 \mu \mathrm{l}$ of $1 \mathrm{M}$ hyamine hydroxyde were added to the stopper's wells in order to collect the ${ }^{14} \mathrm{CO}_{2}$ produced. Cells were washed and lipids were extracted with a chloroform:heptane mix; heptane was added to the samples and the organic phase was collected to measure the palmitate incorporation into the lipid fraction. Palmitate utilization was estimated taking into account both palmitate oxidation and incorporation into the lipid fraction.

RNA isolation and real-time PCR (polymerase chain reaction). Total RNA from $\mathrm{C} 2 \mathrm{C} 12$ cells was extracted by TriPure ${ }^{\mathrm{TM}}$ kit (Roche, Barcelona, Spain), a commercial modification of the acid guanidinium isothiocyanate/phenol/chloroform method (23).

First-strand cDNA was synthesized from total RNA with oligo dT15 primers and random primers pdN6 by using a cDNA synthesis kit (Transcriptor Reverse Transcriptase, Roche). Analysis of mRNA levels for PPAR $\delta$ was performed with primers designed to detect gene products as previously described (24). To avoid the detection of possible contamination by genomic DNA, primers were designed to be located on different exons. The real-time PCR was performed using a commercial kit (LightCycler ${ }^{\mathrm{TM}}$ FastStart DNA Master ${ }^{\text {PLus }}$ SYBR Green I, Roche). The relative amount of all mRNA was calculated using the comparative $\mathrm{C}_{\mathrm{T}}$ method. $18 \mathrm{~S}$ mRNA was used as the invariant control for all studies.

Biochemicals and radiochemicals. Biochemicals were all reagent grade and obtained either from Roche S.A. or from Sigma Chemical Co. (St. Louis, MO, USA); culture media were obtained from Invitrogen (Carlsbad, CA, USA) and radiochemicals were purchased from Amersham (Buckinghamshire, UK).

Statistical analysis. Statistical analysis of the data was performed by means of one-way analysis of variance.

\section{Results and Discussion}

Previous studies have shown that increasing the culture temperature from $37^{\circ} \mathrm{C}$ to $41^{\circ} \mathrm{C}$ results in profound alterations in protein metabolism (22). Our objective was to investigate the protective effect of the cytokine in this particular catabolic condition in murine $\mathrm{C} 2 \mathrm{C} 12$ cells submitted to punctual hyperthermia and to study the role of PPAR $\delta$ in mediating IL15 effects (for more details see Materials and methods). For this purpose, we used $\mathrm{C} 2 \mathrm{C} 12$ cells overexpressing this transcription factor (C2C12-PPAR $\delta$ ) together with cells where the activity of PPAR $\delta$ was completely blocked by overexpression of a PPAR $\delta$ dominant negative mutant (C2C12-PPAR $\delta D N)$. Experiments carried out with these genetically modified cells establish the direct implication of 
Table I. Effect of IL15 and GW501516 on protein degradation in C2C12 myotubes after hyperthermia.

\begin{tabular}{|c|c|c|c|}
\hline & Protein degradation at $37^{\circ} \mathrm{C}$ & Protein degradation at $41^{\circ} \mathrm{C}$ & ANOVA \\
\hline Parental C2C12 & $100 \pm 6(5)^{\mathrm{a}}$ & $139 \pm 6 \quad(4)^{b}$ & $\mathrm{p}<0.05$ \\
\hline C2C12-PPAR & $100 \pm 3(6)^{\mathrm{a}}$ & $150 \pm 8 \quad(5)^{\mathrm{b}}$ & $\mathrm{p}<0.001$ \\
\hline C2C12-PPARd + IL15 & $109 \pm 6(6)^{\mathrm{a}}$ & $172 \pm 6 \quad(6)^{b}$ & \\
\hline C2C12-PPARd + GW501516 & $128 \pm 6(6)^{\mathrm{a}}$ & $166 \pm 18(4)^{b}$ & \\
\hline C2C12-PPARsDN & $100 \pm 5(6)^{\mathrm{a}}$ & $188 \pm 15(6)^{b}$ & $\mathrm{p}<0.001$ \\
\hline C2C12-PPAR8DN + IL15 & $104 \pm 1(6)^{\mathrm{a}}$ & $177 \pm 5 \quad(6)^{b}$ & \\
\hline C2C12-PPARsDN + GW501516 & $115 \pm 2(5)^{\mathrm{a}}$ & $182 \pm 12(4)^{\mathrm{b}}$ & \\
\hline
\end{tabular}

Values for protein degradation are presented as the percentage of the respective control value at $37^{\circ} \mathrm{C}$ of the amino acid radioactivity in the medium versus the total radioactivity incorporated into protein. All data are means \pm SEM. Statistical significance of the results by one-way analysis of variance (ANOVA) in each type of cells separately. Values that are significantly different by ANOVA p $<0.05$ and $<0.001$, and statistically significant difference by post-hoc Duncan test. ${ }^{a, b}$ Different superscripts indicate significant differences $(p<0.05)$ between groups.

PPAR $\delta$ in the regulation of lipid metabolism in $\mathrm{C} 2 \mathrm{C} 12$ myotubes (20).

The results presented in Table I clearly show that hyperthermia resulted in a general increase in protein degradation in all the groups studied. Control parental $\mathrm{C} 2 \mathrm{C} 12$ cells had a $40 \%$ increase in protein degradation while the increase was above $50 \%$ in the genetically-modified cells (C2C12-PPAR $\delta$ and C2C12-PPARSDN). Interestingly, neither IL15 nor the PPAR $\delta$ agonist GW501516 were able to inhibit the increase of protein degradation promoted by hyperthermia. As expected, the same lack of effects for the cytokine and the agonist were observed in the C2C12-PPARSDN cells. The actual overexpression of PPAR $\delta$ and PPAR $\delta$ DN was determined using real-time PCR in comparison to the control parental cells $\left[100 \pm 22(4)^{\mathrm{a}}\right] \mathrm{C} 2 \mathrm{C} 12-\mathrm{PPAR} \delta$ cells $[3533 \pm 489$ $\left.(4)^{b}\right]$ and C2C12-PPARSDN [1193 $\left.\pm 174(4)^{\mathrm{c}}\right]$.

Since no effects of either the cytokine or the agonist were observed on protein degradation, we studied the protein synthesis rates in the same cell culture system. It is important to note that, after hyperthermia, there is an enhanced rate of protein synthesis in cultured cardiomyocytes (25). IL15 increased the protein synthesis rate in native $\mathrm{C} 2 \mathrm{C} 12$ cells exposed to hyperthermia (Table II). Protein synthesis rates were also determined in C2C12-PPAR $\delta$ and $\mathrm{C} 2 \mathrm{C} 12-\mathrm{PPAR} \delta \mathrm{DN}$ cells maintained at $37^{\circ} \mathrm{C}$ or $41^{\circ} \mathrm{C}$ and exposed or not to IL15 or GW501516. Treatments with IL15 or GW501516 did not affect rates of protein synthesis in both cell populations maintained at $37^{\circ} \mathrm{C}$ (Fig. 1A). By contrast, IL 15 and GW501516 promoted an important increase in synthesis (214\% for IL15 and 195\% for GW501516), this being observed only in the C2C12-PPAR $\delta$ cells, while no effect was observed in the C2C12-PPAR $8 D N$ cells (Fig. 1B). These data clearly show that IL15 has a protective effect during hyperthermia which relies on increasing protein synthesis. Since this effect was observed only in the PPAR $\delta$-overexpressing cells this transcription factor is involved in mediating the effects of IL15 in protein synthesis. Indeed, the incubation in the presence of the agonist of PPARS, GW501516, generates a
Table II. Effects of IL15 on protein synthesis in parental C2C12 cells after hyperthermia.

\begin{tabular}{lcc}
\hline Cell treatment & IL15 concentration & Protein synthesis \\
\hline None & None & $100 \pm 4^{\mathrm{a}}$ \\
& $10 \mathrm{ng} / \mathrm{ml}$ & $99 \pm 3^{\mathrm{a}}$ \\
& & $109 \pm 5^{\mathrm{a}}$ \\
Hyperthermia & None & $123 \pm 6^{\mathrm{b}}$ \\
\hline
\end{tabular}

Values for protein synthesis are presented as the percentage of the control value at $37^{\circ} \mathrm{C}$ and were assessed as radioactivity incorporated into $\operatorname{protein} / \mathrm{mg}$ of total protein. All data are means \pm SEM $(n=5)$. Values that are significantly different by ANOVA $\mathrm{p}<0.05$ and $<0.001$, and statistically significant differences were evaluated by post-hoc Duncan test. Different superscripts indicate significant differences ( $p<0.05$ or $<0.001)$ between groups.

similar increase in protein synthesis as observed in IL15. In addition, blocking PPAR $\delta$ activity (dominant negative cells) completely abolishes the effects of IL15 in protein synthesis in $\mathrm{C} 2 \mathrm{C} 12$ under hyperthermia. These results are in agreement with data that showed a capacity of IL15 for increasing protein synthesis under catabolic conditions (13) and, in addition, clarify the transcription factor involved in this action of the cytokine. Indeed, IL15 has been shown to behave as an anabolic cytokine for skeletal muscle influencing protein turnover in this tissue, both in vivo (13) and in vitro (14) under catabolic conditions. It has to be considered that PPAR $\delta$ has been related to hypertrophy at least in red muscle fibers $(12,26)$. Indeed, PPAR $\delta$ regulates PGC1 $\alpha$ (PPAR $\gamma$ coactivator $1 \alpha)$, a protein that participates in the formation and also in the maintenance of red fibers in skeletal muscle (26). In addition, $\mathrm{PGC} 1 \alpha$ has a protective role against loss of protein muscle present in catabolic conditions 
A

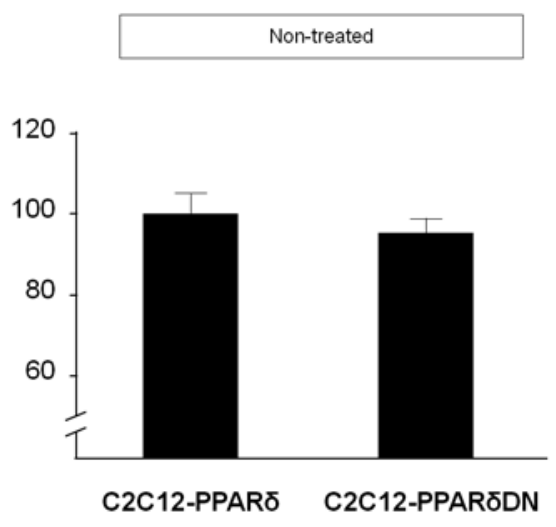

B

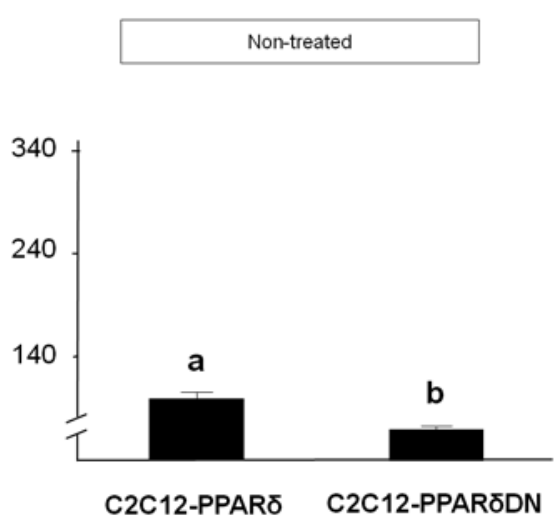

TREATMENT AT $37^{\circ} \mathrm{C}$
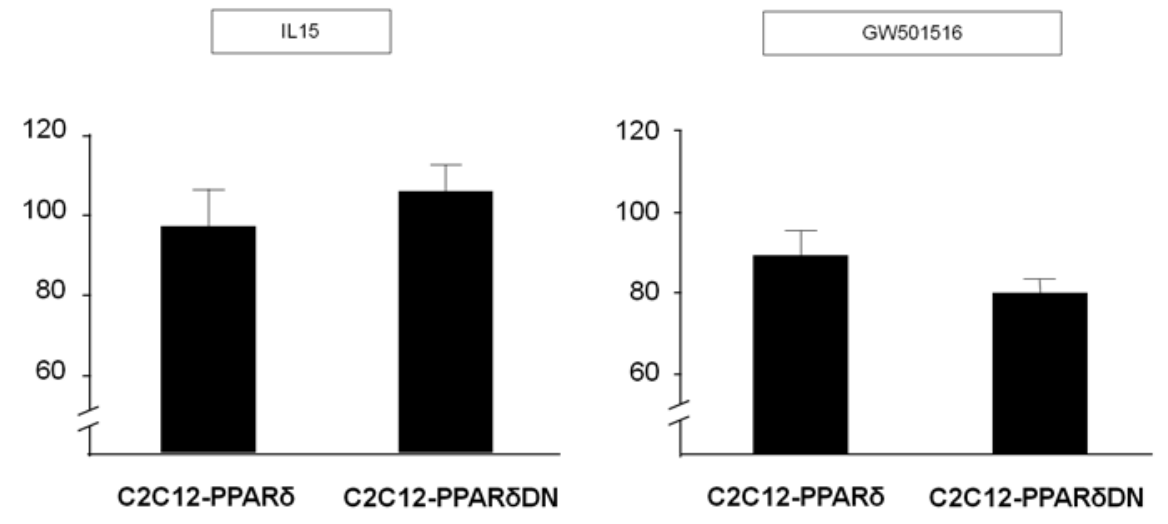

Figure 1. Rates of protein synthesis in $\mathrm{C} 2 \mathrm{C} 12$ cells after hyperthermia. (A), Values for protein synthesis are presented as the percentage of the respective control value at $37^{\circ} \mathrm{C}$ and were assessed as radioactivity incorporated into protein/mg of total protein. (B), Values for protein synthesis are presented as the percentage of the respective control value at $41^{\circ} \mathrm{C}$ and were assessed as radioactivity incorporated into protein $/ \mathrm{mg}$ of total protein. All data are means $\pm \mathrm{SEM}$ ( $\mathrm{n}=5$ ). Values that are significantly different by ANOVA $\mathrm{p}<0.05$ and $<0.001$, and statistically significant differences were evaluated by post-hoc Duncan test. Different superscripts indicate significant differences $(\mathrm{p}<0.05$ or $<0.001)$ between groups.

(27). All these studies agree with the results observed here, supporting a relation between the anabolic effect of IL15 on muscle cells and PPARס. Taking into account all this information, it could be suggested that IL15 activation of PPAR $\delta$ could be upregulating PGC1 $\alpha$ and, consequently, promoting some of the characteristics of type I muscle fiber phenotype.

In addition to its effects on muscle cell protein metabolism, IL15 has been shown to have effects on both carbohydrate (28) and lipid $(18,29,30)$ metabolism; thus IL15, reduces intestinal lipid absorption (30) and, at the level of adipose tissue, it decreases lipogenesis and diminishes lipid uptake $(18,29)$. In the present study we decided to analyze the effects of the cytokine on palmitate uptake and oxidation of this fatty acid in $\mathrm{C} 2 \mathrm{C} 12$ cells and, as can be seen in Fig. 2, IL15 did not influence either uptake or oxidation in control parental cells. However, the overexpression of PPAR $\delta$ is associated with a higher tendency for palmitate utilization and an increased palmitate oxidation in the IL15-treated cells. Interestingly, the results presented here are in agreement with previous results showing an enhanced oxidative capability in muscle (presence of more oxidative fibers) (31) and in $\mathrm{C} 2 \mathrm{C} 12$ cells overexpressing PPAR $\delta$ (12). These results suggest that this transcription factor could also be involved in some of the actions of this cytokine on lipid metabolism in skeletal muscle. Altogether, the results of this study support a role for IL15 in protecting muscle cells during hyperthermia and that the intracellular mechanism involved in this action of the cytokine implicates the transcription factor PPAR $\delta$.

\section{Acknowledgements}

G.F. was supported from the Dirección General de Investigación Científica y Técnica (BFI2002-02186) of the Ministerio de Educación y Ciencia. C.O. was supported by the Programme Alßan, the European Union Programme of High Level Scholarships for Latin America (scholarship no. E05D059293BR). Contract grant sponsor: Instituto de Salud Carlos III of the Ministerio de Sanidad y Consumo; Contract grant number: 06/0907. Contract grant sponsor: Ministerio de Ciencia y Tecnología; Contract grant number: SAF 4744-2005. Contract grant sponsor: Generalitat de Catalunya (SGR/00108). 
PALMITATE UTILIZATION

$\begin{array}{lll}\text { Parental } \mathrm{C} 2 \mathrm{C} 12 & \text { C2C12-PPARO C2C12-PPARסDN }\end{array}$

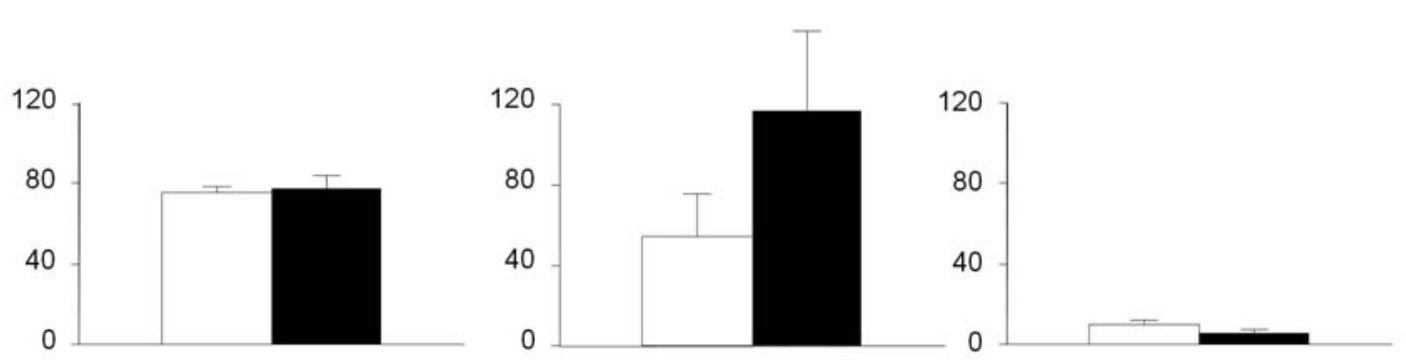

PALMITATE OXIDATION
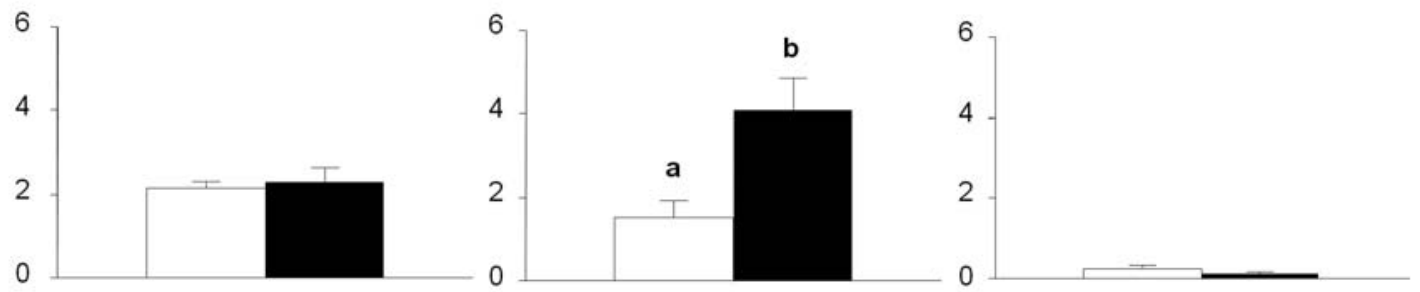

Figure 2. Palmitate oxidation and utilization by $\mathrm{C} 2 \mathrm{C} 12$ cells. The cells were incubated for $3 \mathrm{~h}$. The results are expressed as nmol of palmitate either metabolized or oxidized to $\mathrm{CO}_{2}$ per mg of protein. White bars, non-treated cells. Black bars, IL15-treated cells. All data are means \pm SEM ( $\mathrm{n}=5$ ). Values that are significantly different by ANOVA $\mathrm{p}<0.05$ and $<0.001$, and statistically significant differences were evaluated by post-hoc Duncan test. Different superscripts indicate significant differences $(\mathrm{p}<0.05)$ between groups.

\section{References}

1. Argilés JM, Alvarez B and López-Soriano FJ: The metabolic basis of cancer cachexia. Med Res Rev 17: 477-498, 1997.

2. Argilés JM, Moore-Carrasco R, Fuster G, Busquets S and López-Soriano FJ: Cancer cachexia: the molecular mechanisms Int J Biochem Cell Biol 35: 405-409, 2003.

3. Argilés JM, Busquets S and López-Soriano FJ: The role of uncoupling proteins in pathophysiological states. Biochem Biophys Res Commun 293: 1145-1152, 2002.

4. Guttridge DC, Mayo MW, Madrid LV, Wang CY and Baldwin AS Jr: NF-kappaB-induced loss of MyoD messenger RNA: possible role in muscle decay and cachexia. Science 289: 2363-2366, 2000.

5. Wyke SM, Russell ST and Tisdale MJ: Induction of proteasome expression in skeletal muscle is attenuated by inhibitors of NF-kappaB activation. Br J Cancer 91: 1742-1750, 2004.

6. Penner G, Gang G, Sun X, Wray C and Hasselgren PO: C/EBP DNA-binding activity is upregulated by a glucocorticoiddependent mechanism in septic muscle. Am J Physiol 282 : R439-R444, 2002.

7. Costelli P, Muscaritoli M, Bossola M, Moore-Carrasco R, Crepaldi S, Grieco G, Autelli R, Bonelli G, Pacelli F, LopezSoriano FJ, Argilés JM, Doglietto GB, Baccino FM and Rossi Fanelli F: Skeletal muscle wasting in tumor-bearing rats is associated with MyoD down-regulation. Int J Oncol 26: 1663-1668, 2005.

8. Moore-Carrasco R, García-Martínez C, Busquets S, Ametller E, Barreiro E, López-Soriano FJ and Argilés JM: The AP-1/CJUN signaling cascade is involved in muscle differentiation: implications in muscle wasting during cancer cachexia. FEBS Lett 580: 691-696, 2006

9. Dressel U, Allen TL, Pippal JB, Rohde PR, Lau P and Muscat GE: The peroxisome proliferator-activated receptor beta/delta agonist, GW501516, regulates the expression of genes involved in lipid catabolism and energy uncoupling in skeletal muscle cells. Mol Endocrinol 17: 2477-2493, 2003.
10. Chinetti G, Griglio S, Antonucci M, Torra IP, Delerive P, Majd Z, Fruchart JC, Chapman J, Najib J and Staels B: Activation of proliferator-activated receptors alpha and gamma induces apoptosis of human monocyte-derived macrophages. J Biol Chem 273: 25573-25580, 1998

11. Ferré P: The biology of peroxisome proliferator-activated receptors: relationship with lipid metabolism and insulin sensitivity. Diabetes 53: S43-S50, 2004.

12. Grimaldi PA: Regulatory role of peroxisome proliferator-activated receptor delta (PPAR delta) in muscle metabolism. A new target for metabolic syndrome treatment? Biochimie 87: 5-8, 2005.

13. Carbó N, López-Soriano J, Costelli P, Busquets S, Alvarez B, Baccino FM, Quinn LS, López-Soriano FJ and Argilés JM: Interleukin-15 antagonizes muscle protein waste in tumourbearing rats. Br J Cancer 83: 526-531, 2000.

14. Quinn LS, Anderson BG, Drivdahl RH, Alvarez B and Argilés JM: Overexpression of interleukin-15 induces skeletal muscle hypertrophy in vitro: implications for treatment of muscle wasting disorders. Exp Cell Res 280: 55-63, 2002.

15. Carbó N, López-Soriano J, Costelli P, Alvarez B, Busquets S, Baccino FM, Quinn LS, López-Soriano FJ and Argilés JM: Interleukin-15 mediates reciprocal regulation of adipose and muscle mass: a potential role in body weight control. Biochim Biophys Acta 1526: 17-24, 2001.

16. Alvarez B, Carbó N, López-Soriano J, Drivdahl RH, Busquets S, López-Soriano FJ, Argilés JM and Quinn LS: Effects of interleukin-15 (IL-15) on adipose tissue mass in rodent obesity models: evidence for direct IL-15 action on adipose tissue. Biochim Biophys Acta 1570: 33-37, 2002.

17. Quinn LS, Strait-Bodey L, Anderson BG, Argiles JM and Havel PJ: Interleukin-15 stimulates adiponectin secretion by 3T3L1 adipocytes: evidence for a skeletal muscle-to-fat signaling pathway. Cell Biol Int 29: 449-457, 2005.

18. Almendro V, Busquets S, Ametller E, Carbó N, Figueras M, Fuster G, Argilés JM and López-Soriano FJ: Effects of interleukin-15 on lipid oxidation: disposal of an oral [(14)C]-triolein load. Biochim Biophys Acta 1761: 37-42, 2006. 
19. Bastie C, Luquet S, Holst D, Jehl-Pietri C and Grimaldi PA: Alterations of peroxisome proliferator-activated receptor delta activity affect fatty acid-controlled adipose differentiation. J Biol Chem 275: 38768-38773, 2000.

20. Holst D, Luquet S, Kristiansen K and Grimaldi PA: Roles of peroxisome proliferator-activated receptors delta and gamma in myoblast transdifferentiation. Exp Cell Res 288: 168-176, 2003.

21. Alvarez B, Quinn LS, Busquets S, López-Soriano FJ and Argilés JM: Direct effects of tumor necrosis factor alpha (TNF-alpha) on murine skeletal muscle cell lines. Bimodal effects on protein metabolism. Eur Cytokine Netw 12: 399-410, 2001.

22. Smith HJ, Khal J and Tisdale MJ: Downregulation of ubiquitindependent protein degradation in murine myotubes during hyperthermia by eicosapentaenoic acid. Biochem Biophys Res Commun 332: 83-88, 2005.

23. Chomczynski P and Sacchi N: Single-step method of RNA isolation by acid guanidinium thiocyanate-phenol-chloroform extraction. Anal Biochem 162: 156-159, 1987.

24. Fuster G, Busquets S, Ametller E, Olivan M, Almendro V De Oliveira CC, Figueras M, López-Soriano FJ and Argilés JM: Are peroxisome proliferator-activated receptors involved in skeletal muscle wasting during experimental cancer cachexia? Role of beta2-adrenergic agonists. Cancer Res 67: 6512-6519, 2007.

25. Marber MS: Stress proteins and myocardial protection. Clin Sci (Lond) 86: 375-381, 1994
26. Schuler M, Ali F, Chambon C, Duteil D, Bornert JM, Tardivel A, Desvergne B, Wahli W, Chambon P and Metzger D: PGC1alpha expression is controlled in skeletal muscles by PPARbeta, whose ablation results in fiber-type switching, obesity, and type 2 diabetes. Cell Metab 4: 407-414, 2006.

27. Sandri M, Lin J, Handschin C, Yang W, Arany ZP, Lecker SH, Goldberg AL and Spiegelman BM: PGC-1alpha protects skeletal muscle from atrophy by suppressing $\mathrm{FoxO} 3$ action and atrophyspecific gene transcription. Proc Natl Acad Sci USA 103: 16260-16265, 2006.

28. Busquets S, Figueras M, Almendro V, López-Soriano FJ and Argilés JM: Interleukin-15 increases glucose uptake in skeletal muscle. An antidiabetogenic effect of the cytokine. Biochim Biophys Acta 1760: 1613-1617, 2006.

29. López-Soriano J, Carbó N, Almendro V, Figueras M, Ribas V, Busquets S, López-Soriano FJ and Argilés JM: Rat liver lipogenesis is modulated by interleukin-15. Int J Mol Med 13: 817-819, 2004.

30. Almendro V, Carbó N, Busquets S, López-Soriano J, Figueras M, Ametller E, Argilés JM and López-Soriano FJ: Interleukin-15 decreases lipid intestinal absorption. Int J Mol Med 15: 963-967, 2005.

31. Luquet S, Lopez-Soriano J, Holst D, Fredenrich A, Melki J, Rassoulzadegan M and Grimaldi PA: Peroxisome proliferatoractivated receptor delta controls muscle development and oxidative capability. FASEB J 17: 2299-2301, 2003. 